\title{
SISTEM PENGGAJIAN GURU BIMBINGAN BELAJAR (ANALISIS PADA DAMPAK PERSAINGAN)
}

\section{TEACHER PAYMENT SYSTEM OF LEARNING SUPERVISION (ANALYSIS TO THE CONTETITION IMPACT)}

\author{
Y.Triwidatin, S. Anwar \\ Program Studi AkuntansiFakultas Ekonomi Universitas DjuandaBogor \\ yuppygumelar@gmail.com, saeful.anwar@unida.ac.id
}

\begin{abstract}
This study aims to analyze the effect of salary and motivation on teacher performance. The population of this study was 137 tutors of tutoring in Bogor Regency. The sample in this study consisted of 135 people who were determined by proportional random sampling. Data collection was carried out using a questionnaire. The collected data were thenanalyzed using statistics in the form of Structural Equation Modeling (SEM) with AMOS. The results showed that: 1) salary had a significant effect on teacher motivation, (2) salary had a significant effect on teaching skills, (2) motivation had a significant effect on teaching skills, (3) teaching skills had a significant effect on teacher performance, (4) salary (6) motivation has a significant effect on teacher performance, (7) salary has a significant effect on teacher performance through teaching skills (8) motivation has a significant effect on teacher performance through teaching skills.
\end{abstract}

Keywords : competition, bimbel, Payment System.

\begin{abstract}
ABSTRAK
Penelitian ini bertujuan untuk menganalisis pengaruh gaji dan motivasi terhadap kinerja guru. Populasi penelitian ini adalah gur bimbingan belajar di Kabupaten Bogor sebanyak 137 orang. Sampel dalam penelitian ini terdiri dari 135 orang yang ditentukan melalui proportional random sampling. Pengumpulan data dilakukan dengan menggunakan kuesioner. Data yang terkumpul kemudian dianalisis dengan menggunakan statistik dalam bentuk Structural Equation Modeling (SEM) dengan AMOS. Hasil penelitian menunjukkan bahwa: 1) gaji berpengaruh signifikan terhadap motivasi guru, (2) gaji pengaruh signifikan terhadap keterampilan mengajar, (2) motivasi berpengaruh signifikan terhadap keterampilan mengajar, (3) keterampilan mengajar berpengaruh secara signifikan terhadap kinerja guru, (4) gaji berpengaruhsignifikan terhadap kinerja guru, (6) motivasi berpengaruh signifikan terhadap kinerja guru, (7) gaji berpengaruh signifikan terhadap kinerja guru melalui keterampilan mengajar (8) motivasiberpengaruh signifikan terhadap kinerja guru melalui keterampilan mengajar.

Kata Kunci : Persaingan, Bimbel, Sistem Penggajian
\end{abstract}




\section{PENDAHULUAN}

Di Indonesia ilmu pengetahuan dan teknologi terus berkembang. Tuntutan masyarakat semakin kompleks dan persainganpun semakin ketat, apalagi dalam menghadapi era globalisasi dan perdagangan bebas, untuk itu perlu disiapkan sumber daya manusia yang berkualitas, salah satu upaya meningkatkan sumber daya manusia adalah melalui jalur pendidikan. Pendidikan merupakan salah satu faktor utama bagi pengembangan sumber daya manusia karena pendidikan diyakini mampu meningkatkan sumber daya manusia sehingga dapat menciptakan manusia produktif yang mampu memajukan bangsanya, (Kunaryo, 2000). Pendidikan dalam arti luas didalamnya terkandung pengertian mendidik, membimbing, mengajar dan melatih. Dalam keseluruhan proses pendidikan di sekolah, kegiatan belajar merupakan kegiatan yang paling pokok.

Tujuan pendidikan nasional berdasarkan UU RI NO. 20 tahun 2003 tentang Sistem Pendidikan Nasional, sebagai berikut : Pendidikan nasional bertujuan untuk berkembangnya potensi peserta didik agar menjadi manusia yang beriman dan bertaqwa kepada Tuhan YME, berakhlak mulia, sehat, berilmu, cakap, kreatif, mandiri dan menjadi warga Negara yang demokratis serta bertanggung jawab. Tujuan pendidikan yang hendak dicapai pemerintah Indonesia adalah mencerdaskan kehidupan bangsa. Oleh karena itu pemerintah sejak orde baru telah mengadakan perluasan kesempatan memperoleh pendidikan bagi seluruh Rakyat Indonesia. Hal ini sesuai dengan bunyi pasal 31 ayat 1 UUD 1945, yang menyatakan bahwa: "Tiap-tiap warga Negara berhak mendapat pengajaran". Seorang guru perlu menyadari bunyi dan isi pasal ayat Undang Undang Dasar tersebut, setiap siswa berhak mendapatkan pengajaran yang sama. Dalam tugasnya sehari-hari guru dihadapkan pada suatu permasalahanyaitu ia harus memberi pengajaran yang sama kepada siswa yang berbeda-beda. Perbedaan itu berasal dari lingkungan kebudayaan, lingkungan sosial, jenis kelamin.
Salah satu tujuan siswa bersekolah adalah untuk mencapai prestasi belajar yang maksimal sesuai dengan kemampuannya. Penyelenggara pendidikan dilaksanakan melalui 2 (dua) jalur yaitu jalur pendidikan sekolah dan jalur pendidikan luar sekolah. Jalur pendidikan sekolah merupakan pendidikan yang diselenggarakan di sekolah melalui kegiatan belajar mengajar secara berjenjang dan berkesinambungan. Jalur pendidikan luar sekolah merupakan pendidikan yang diselenggarakan diluar sekolah melalui kegiatan belajar-mengajar yang tidak harus berjenjang dan berkesinambungan. Pendidikan keluarga merupakan bagian dari jalur pendidikan luar sekolah yang diselenggarakan dalam keluarga dan yang memberi keyakinan agama, nilai budaya, nilai moral dan keterampilan (UU RI No. 20 Tahun 2003).

Di zaman yang semakin maju seperti sekarang mengakibatkan perkembangan teknologi kian pesat. Persaingan diberbagai bidang semakin meningkat. Kebutuhan masyarakan bisa terpenuhi hanya dengan mengandalkan telepon genggam termasuk dalam hal belajar. Kemudahan inilah yang kemudian dimanfaatkan untuk pengembangkan teknologi dibidang pembelajaran. Salah satunya adalah adanya bimbingan belajar online.

Bimbingan belajar atau bimbel adalah suatu kegiatan yang dilakukan untuk memberikan bantuan kepada peserta didik dalam upaya meningkatkan prestasi atau hasil belajar yang lebih optimal dilembaga siswa menuntut ilmu. Tujuannya yaitu untuk mengatasi kesulitan-kesulitan beajar yang dihadapi sihingga dapat terpecahkan dan mendapatkan beberapa cara bagaimana belajar optimal dan efisien. Selain itu bimbel mempunyai fungsi lain yait membantu memahami dan menyerap pelajaran juga bisa membantu siswa mengerti dengan cepat, tepat dan benar bila ada materi atau soal yang sulit di sekolah serta lebih efektif dan pandai bersosialisasi karena didalam suatu institut bimbel terdiri dari siswa yang berbeda sekoah, dan siswa pun mndapatkan pergaulan yang positif. Waktu bimbingan belajar dilakukan diluar jam belajar efektif disekolah 
atau menyesuaikan dengan kebutuhan para siswanya, yaitu dilakukannya proses pembelajaran bimbingan belajar tersebut pada waktu sore hari sepulang sekolah sampai menjelang malam.

Dengan berbagai kebutuhan untuk belajar yang lebih optimal dan efisien inilah memunculkan peluang untuk mendirikan sebuah institute bimbingan belajar diberbagai daerah. Dari setiap tempat bimbel yang tersedia mempunyai cara masing-masing. Bimbel online merupakan terobosan baru untuk memudahkan siswa dalam belajar. Metode pembelajaran yang disajikan bervariasi dan cendrung mengikuti perkembangan teknologi zaman sekarang. Sistem belajar yang tidak rumit dan bisa dilakukan dimanapun, kapanpun, atau dengan sispapun, kemudian banyak menarik minat siswa untuk beralih dari bimbel konvensional ke bimbel online.

Dampak yang timbul dari persaingan bimbel konvensional dengan bimbel online ini, yang pertama adalah dari jumlah siswa yang berkurang pada bimbel konvensional. Hal ini dikarenakan banyak siswa yang beralih ke bimbel online dengan berbgai pertimbangan, mualai dari biaya pembelajaran, fleksibilitas waktu yang bisa digunakan, serta bisa diakes atau dipelajari hanya lewat telepon genggam tanpa harus datang ketempat bimbel. Bimbel online tersedia dalam sebuah aplikasi yang dengan mudah dapat di download kemudian diaktivasi atau daftar. Selain itu persaingan ini juga berdampak pada honor guru disanabesarannyadiperhitungkan berdasarkan jumlah siswa dan jam mengajar dikelas.

Dalam penelitian ini metode pengumpulan data yang dipakai, adalah :

\section{Metode angket / kuesioner}

Dalam penelitian ini, angket digunakan untuk mengetahui seberapa besar minat siswa mengikuti bimbel konvensional atau bimbel online.

\section{Metode dokumentasi}

Metode dokumentasi digunakan untuk mengetahui peningkatan nilai yang dapat di raih siswa dengan mengikuti bimbel.
1. Penelitian ini hanya dilakukan di Cibinong Kabupaten Bogor, Jawa Barat, Indonesia

2. Subyek penelitian adalah siswa yang mengikuti bimbingan belajar

3. Penelitian ini hanya terbatas mendiskusikan variable yang sudah ditentukan.

Berdasarkan uraian di atas, maka dapat dirumuskan suatu permasalahan sebagai berikut :

1. Bagaimana pengaruh persaingan bimbel konvensional dengan bimbel online

2. Apakah benar persaingan bimbel konvensional dengan bimbel online berdampak pada berkurangnya siswa dan honor guru bimbingan belajar di Cibinong Kabupaten Bogor

3. Apakah ada cara untuk mengatasi persaingan agar bimbingan belajar konvensional tetap bisa diminati di tengah perkembangan bibingan belajar online

Tujuan mengadakan penelitian ini adalah :

1. Untuk mengetahui pengaruh dari persaingan bimbel konvensional di Cibinong Kabupaten Bogor dengan bimbel online yang saat ini sedang berkembang

2. Untuk mengetahui kebenaran dari suatu persepsi bahwa persaingan bimbel konvensional dengan bimbel online berdampak pada berkuranganya siswa dan honor guru di Cibinong Kabupaten Bogor

3. Untuk mengetahui proses pembaharuan pembelajaran pada bimbingan belajar di Cibinong kabupaten Bogor supaya tetap bisa mempertahankan eksistensinya di dunia pendidikan

Adapun manfaat dari penelitian ini di harapkan dapat memberikan manfaat sebagai berikut :

1. Manfaat Teoritis :

Dapat mengetahui pengaruh persaingan bimbingan belajar yang dilakukan secara konvensional dengan bimbingan belajar online yang saat ini sedang berkembang 
2. Manfaat Praktis :

Dapat dijadikan sebagai dasar atau acuan untuk mempertahankan eksistensi bimbingan belajar konvensional sehingga dampak yang ditimbulkan dari persaingan tersebut tidak begitu signifikan, baik dengan merubah atau menambah metode pembelajaran, maupun sistem promosi yang menarik

3. Manfaat bagi peneliti :

a. Dapat menerapkan ilmu pengetahuan yang sudah didapat sebelumnya

b. Mengetahui sistematika yang berjalan pada bimbingan belajar konvensional dan bimbingan belajar online

c. Menambah wawasan dan pengalaman baru dalam melakukan penelitian dengan melihat fenomena yang sedang terjadi

\section{Pengertian Persaingan Bisnis}

Persainga usaa (bisnis) adalah istilah yang sering muncul dalam literatur yang menuliskan perihal aspek hukum persaingan bisnis. Persaingan bersadal dari bahasa Inggris kompetition yang artinya persaingan itu sendiri atau kegiatan bersaing, pertandingan dan komperisi. Persaingan adalah ketika suatu organisasi atau perorangan berlomba untuk mencapai suatu tujuan yang diinginkan seperti konsumen, pangsa pasar, atau sumber daya yang dibutuhkan. Sedangkan dalam kamus managemen, persaingan adalah usahausaha dari dua pihak atau lebih perusahaan yang masing-masing bergiat memperoleh konsumen atau pesanan dengan menawarkan harga atau syarat yang paling menguntungkan. Dalam kasus manajemen persaingan terdiri dari :

a. Persainga sehat (healthy competition)

Persaingan antara perusahaanperusahaan atau pelaku bisnis yang diyakini tidak akan menuruti atau melakukan tindakan yang tidak layak dan cendrung mengedepankan etika-etika bisnis.

b. Persaingan gorok leher (cut throat competition)

Persaingan ini merupakan bentuk persaingan yang tidak sehat, dimana terjadi perebutan pasar antara beberapa pihak yang melakukan usaha yang mengarah melakukan pada menghalalkan segala cara untuk menjatuhkan lawan, sehingga salah satu tersingkir dari padar dan salah satunya menjual barang atau jasa di bawah harga yang berlaku dipasar

1. Dampak persaingan bisnis

Persaingan bisnis yang terjadi pada saat sekarang ini mempunyai beberapa dampak bagi kehidupan sosial bagi ekonomi masyarakat, yaitu yang bersifat positif dan negatif. Adapun dampaknya yaitu sebagai berikut :

a. Dampak positif persaingan bisnis, meliputi :

1. Terjadinya peningkatan produk atau jasa yang ditawarkan

2. Lebih terjaminnya persediaan produk

3. Meningkatkan kualitas sumber daya manusia

4. Terjadinya kewajaran harga karena efisiensi ekonomi

5. Meningkatkan kualitas perkembangan kualitas teknologi

b. Dampak negatif persaingan bisnis, meliputi :

1. Ada kemungkinan terjadinya pelanggaran bisnis dengan menghalalkan segala cara agar bisnisnya berkembang.

2. Kesulitan tumbuhnya bisnis pemula

3. Terjadinya perang harga yang merugikan pihak terkait 
4. Dapat menghasilkan bisnis monopoli dalam persaingan pasar

2. Perkembangan persainga bisnis pada bidang pendidikan dengan teknologi dan honor pengajar pada bimbingan belajar. Teknologi adalah keseluruhan sarana untuk menyediakan barangbarang yang diperlukan bagi kelangsungan dan kenyamanan hidup manusia. Kemudahan dalam mendapatkan pembelajaran yang optimal saat ini begitu mudah dengan adanya perkembangan teknologi. Selain belajar mengajar yang terjadi disekolah, kini ada alternatif lain untuk melakukan itu, salah satunya adalah bimbingan belajar, baik secara konvensional maupun online.

Bimbingan belajar adalah suatu kegiatan yang dilakukan untuk memberikan bantuan kepada peserta didik dalam upaya meningkatkan prestasi atau hasil belajar yang lebih optimal dilembaga tempat siswa menuntut ilmu. Banyak keuntungan yang didapat oleh siswa yang megikuti bimbel. Selain untuk meningkatkan prestasi belajar siswa terhadap mata pelajaran yang dianggap sulit, serta mampu mengembangkan kemampuan untuk bersosialisasi. Sedangan bimbingan belajar online yaitu suatu kegiatan untuk membantu pembelajaran siswa yang dilakukan atau siakses melalui sistem online. Ada beberapa keunggulan bimbingan belajar online, antara lain :

a. Dapat mengulai materi yang diberikan atau setiap materi yang disampaikan oleh pengajar

b. Waktu bimbingan belajar online tidak terbatas

c. Kemudahan mengakses materi

d. Harga yang ditawarkan relatif ekonomis dibandingan dengan bimbingan belajar konfensional

Kemudian, dengan kemudahan yang sedang berkembang saat ini banyak siswa yang beralih ke bimbel online, dengan berbagai pertimbangan yang di sajikan sehingga bimbel konfensional mengalami penurunan jumlah siswa. Pengajar atau guru dalam kamus besar bahasa Indonesia adalah orang yang pekerjaannya mengajar. Tugas utama seorang guru adalah mengajar, yaitu membuat orang lain memahami sesutu yang belum dipahami sebelumnya. Guru atau pengajar dalam sebuah bimbingan belajar konvensional di gaji berdasarkan jumlah jam mengajarnya

Menurut Drs. H. Wahyu S.P Hasibuan, 2012.118 gaji atau honor termasuk komponan dari kompensasi. Kompensasi adalah semua pendapatan yang berbentuk uang, barang langsung atau tidak langsung yang diterima karyawan sebagai imbalan atas jasa yang diberikan kepada perusahaan atau instansi.

Kompetensi dibedakan menjadi dua, yaitu :
1. Kompetensi
langsung
(direct compansation) berupa :

a. Gaji adalah balas jasa yang dibayar secara periodik kepada karyawan tetap serta mempunyai jaminan yang pasti. Maksudnya gaji akan tetap dibayarkan walaupun pekerja tersebut tidak masuk kerja.

b. Upah dan honor adalah balas jasa yang dibayarkan kepada pekerja harian dengan berpedoman atas perjanjian yang disepakati pembayarannya.

c. Upah insentif adalah tambahan balas jasa yang diberikan kepada karyawan tertentu yang prestasinya diatas prestasi standar. Upah insentif ini merupakan alat yang dipergunakan pendukung prinsip adil dalam pemberian kompensasi.

2. Kompensasi tidak langsung (indirect compensation/employee welfare atau kesejahteraan karyawan)

Sistem penggajian adalah mengembalikan sekumpulan prosedur prosedur yang memungkinkan perusahaan untuk menarik, menahan dan memotivasi staf yang diperlukan, serta untuk mengendalikan biaya pembayaran gaji. Karena tidak satu pola yang dapat digunakan secara universal maka prosedur ini harus disesuaikan dengan kebijakan gaji tiap-tiap organisasi dan hendaknya 
disadarkan atas kebijakan yang dianggap adil.Setiap penggajian dan pengupahan adalah jaringan prosedur yang terdiri dari sebagai berikut :

a. Prosedur pencatatan waktu hadir

Prosedur ini bertujuan untuk mencatat waktu hadir guru dari dimulainya proses belajar hingga selesai.

b. Proses pencatatan waktu kerja

Dalam perusahaan manufaktur yang produksinya berdasarkan pesanan, pencatatan waktu kerja diperlukan bagi karyawan yang bekerja difungsi produksi untuk keperluan distribusi biaya dan upah karyawan, sedang untuk di bimbingan belajar di Cibinong Kabupaten Bogor dihitung berdasarkan jumlah waktu mengajar yang berdurasi 90 menit setiap mata pelajaran.

c. Prosedur pembuatan daftar gaji dan upah

Data yang dipakai sebagai dasar pembuatan daftar gaji adalah surat-surat keputusan mengenai pengangkatan karyawan baru, daftar gaji bulan sebelumnya dan daftar hadir.

d. Prosedur distribusi biaya gaji atau honor

Biaya tenaga kerja didistribusikan kepada departemen-departemen yang menikmati manfaat tenaga kerja.

e. Prosedur pembayaran gaji dan honor

Prosedur ini melibatkan fungsi akuntansi dan fungsi keuangan. Fungsi akuntansi membuat perintah pengeluaran kas kepada fungsi keuangan untuk

\section{Hipotesis}

menulis cek guna pembayaran gaji dan upah.

Berdasarkan teori-teori yang telah diuraikan maka persaingan bisnis pada bidang pendidikan non formal seperti bimbingan belajar terdapat persaingan antara bimbingan belajar konvensional dengan bimbingan belajar online yang berdampak pada berkurangnya siswa karena banyak yang beralih pada bimbingan belajar online yang dianggap lebih mudah sehingga hal tersebutpun berdampak pada gaji atau upah guru pengajar dibimbingan belajar konvensional. Hal ini dikarenakan honor atau upah guru dibimbingan belajar dihitung berdasarkan jumlah siswa dan jam mengajar dikelas.

Penelitian merumuskan sebuah hipotesis bahwa ada pengaruh persaingan bimbel konvensional dengan bimbel online yang berdampak pada berkurangnya siswa dan honor guru di Cibinong Kabupaten Bogor.

\section{Kerangka Berfikir}

Pengaruh persaingan bimbel konvensional dengan bimbel online

Seperti sekolah yang lazim ditemui, bimbel konvensional diadakan di dalam ruang kelas. Beberapa murid berkumpul di ruangan yang sama, didampingi dengan satu mentor untuk tiap pelajaran. Jumlah peserta kelas relatif lebih kecil dari sekolah, maksimal 20 orang. Sementara sesi belajar dihitung per minggu, antara 2-4 kali pertemuan. Mengikuti les di bimbel konvensional, biasanya jadi ajang untuk mendapat teman baru dari luar sekolah. Setidaknya, kamu dapat merasakan kompetisi belajar antara siswa-siswa dalam satu kota yang sama. Modul materi pun menjadi fasilitas standar yang dapat diterima. Namun, tak sedikit pula yang mengenakan biaya tambahan untuk mengadakan tryout.

Saat ini banyak sekali situs-situs yang menyediakan seri-seri kursus online dengan berbagai topik. Mendengar penjelasan di depan kelas diganti dengan menonton video materi. Banyak juga situs yang menyediakan akses secara cuma-cuma. Namun, murid tidak bisa melakukan konsultasi personal secara langsung dengan mentor pemateri. Di kursus online, murid juga dituntut untuk dapat 
belajar secara mandiri. Bagi yang ingin mendapat pendampingan belajar yang lebih personal, dapat memanggil guru privat ke rumah. Bila biasanya belajar diadakan secara berkelompok (satu guru banyak murid), guru privat hanya melayani satu murid. Keunggulannya adalah, murid dapat belajar sesuai batas kemampuannya saat ini.

Bila kelas di bimbel konvensional berbentuk ruangan, maka kelas di bimbel online terjadi di dalam grup aplikasi online chat. Kompetisi yang terjadi tidak hanya dengan sesama murid di satu kota tertentu, bahkan bisa datang dari seluruh nasional. Hal ini tentunya membuat jaringan pertemanan yang diperoleh menjadi lebih luas (Triwirdatin,2019).

Pengaruh dampak berkurangnya jumlah siswa yang mengikuti bimbel konvensional Jika dibandingkan dengan bimbel konvensional seperti Ganesha Operation, Nurul Fikri, Inten, Salemba Group hingga Sony Sugema College, tentu harga yang ditawarkan bimbel online sangat menggiurkan. Harga bimbel konvensional cukup bervariatif, dari rentang Rp4,9 juta hingga RP 19,5 juta untuk paket SMA selama satu tahun. Di sisi lain, jenjang tarif bimbel online untuk jenjang SMA plus paket UN dan SBMPTN selama satu tahun dimulai dari harga Rp790 ribu hingga RP1,4 juta.

Kendati demikian, harga bimbel online yang murah tidak sekonyong-konyong akan menghapus bimbel konvensional. Hal tersebut disampaikan oleh pengamat pendidikan Doni Koesoema, baginya bimbel online merupakan sebuah tren yang tak bisa dihalangi sebagai dampak kemajuan teknologi. Dengan harga yang lebih mahal dari bimbel online, bimbel konvensional masih menjadi pilihan. Bimbel konvensional masih menjadi pilihan selama kualitas guru yang ditawarkan bisa membantu anak mendapatkan nilai terbaik di sekolah. bimbel online tidak menjamin memiliki guru-guru berkualitas, begitu pun sebaliknya. Oleh karena itu ia meminta agar jangan sampai terjadi generalisir kualitas guru di bimbel online. Kualitas guru ini yang akan membuat orang tua rela merogoh kocek dalam demi buah hatinya. Ia menjelaskan sayangnya ada orang tua yang asal memilihkan bimbel konvensional tanpa tahu kualitas pengajarnya. Meski bayar mahal, orang tua masih memilih mempercayakan anakanaknya pada sosok guru yg baik, menjadi teladan, dengan demikian, urusannya bukan sekadar bimbel, tapi pendidikan karakter

\section{Pengaruh honor guru pada bimbel konvensional}

Pembelajaran di kelas-kelas Bimbingan belajar dilakukan dengan tujuan untuk mempersiapkan siswa terampil dalam mengerjakan soal-soal ujian. Pembelajaran dilakukan dengan fokus bagaimana siswa dapat mengerjakan soal dengan mudah dan cepat. Materi pelajaran diberikan secara singkat dan padat. Dalam mencapai target materi yang sangat padat biasanya kelas-kelas di bimbingan belajar tersedia proyektor sebagai alat Bantu. Pembelajaran semacam ini mungkin sesuai untuk program intensif dalam menghadapi ujian masuk PTN maupun untuk kelas yang dirancang khusus untuk mempersiapkan siswa mengikuti ujian masuk PTN. Akan tetapi pembelajaran yang berbeda harus dilakukan untuk kelas regular di mana pemahaman terhadap materi pelajaran tidak dapat diabaikan. Oleh karena itu diperlukan pendekatan yang berbeda antara pembelajaran program regular dan program intensif. Pemisahan semacam inilah yang belum disadari dalam penyelenggaraan bimbingan belajar yang ada. Jika dilihat dari sudut pandang metode belajar modern yang berkembang saat ini maka pembelajaran yang berlangsung di bimbingan belajar (khususnya pada program regular), meskipun telah dirancang sedemikian rupa agar tidak membosankan, pada dasarnya dapat digolongkan sebagai berikut. Pembelajaran berpusat pada guru/pengajar (teacher centered learning) bukan pembelajaran berpusat aktivitas (activity driven learning). Menurut penelitian pembelajaran lebih efektif melalui pengalaman dan dengan siswa langsung berinteraksi dengan bahan yang sedang dipelajari. Pembelajaran di bimbingan belajar masih menempatkan guru sebagai pemberi materi dan siswa dianggap sebagai wadah yang harus diisi dengan ilmu.

Pembelajaran berbasis media tunggal (singlemedia based learning) bukan pembelajaran 
berbasis multimedia (multimedia based learning). Multimedia di sini bukan berarti komputer yang dilengkapi multimedia. Tetapi, multimedia adalah penggunaan berbagai macam media yang dapat memudahkan siswa memahami materi pelajaran. Selama ini dianggap dengan menggunakan alat Bantu proyektor seorang pengajar merasa telah menggunakan media belajar. Padahal penggunaan proyektor hanya memanfaatkan media tunggal yang efektivitasnya lebih rendah dibanding multimedia.

Pembelajaran berbasis pada isi (content based learning) bukan pembelajaran berbasis konteks (context based learning). Materi pelajaran yang akan di kelas bimbingan belajar biasanya telah terjadwal dan tiap materi harus selesai pada tiap pertemuan. Setiap siswa dianggap sama dalam menyerap pelajaran sehingga materi akan diselesaikan sesuai jadwal sehingga selesainya materi dianggap juga dengan pahamnya siswa terhadap materi yang sudah disampaikan. Padahal setiap siswa berbeda dalam menyerap pelajaran dan merupakan tindakan yang tidak bertanggung jawab apabila kita menganggap selesainya materi juga berarti seluruh siswa memahami materi yang diberikan.

\section{METODE PENELITIAN}

\section{Pemilihan Subjek Penelitian}

\section{A. Populasi}

Populasi dalam penelitian ini adalah seluruh siswa dan guru bimbingan belajar di Cibinong kabupaten Bogor, adalah yang terdiri dari 80 orang siswa yang diambil acak dari setiap tempat kursus, serta tenaga pengajar atau guru yang berjumlah 20 orang.

B. Sampel dan Tekhnik Sampling.

Pengambilan sampel menggunakan metode sampling jenuh yaitu teknik penentuan sampel bila semua anggota populasi dijadikan sebagai sampel. Banyaknya sampel dalam penelitian ini adalah 80 orang siswa dan 20 orang guru yang diambil secara acak atau rendom.

C. Variabel Penelitian

Dalam penelitian ini terdapat 2 variabel, yaitu:
1. Variabel Bebas (X)

Variabel bebas dalam penelitian ini, adalah persaingan bimbel konvensional dan bimbel online.

2. Variabel terikat (Y)

Variabel terikat dalam penelitian ini adalah dampak persaingan pada berkurangnya jumlah siswa dan honor guru pada bimbingan belajar di Cibinong kabuaten Bogor..

\section{Pengumpulan Data}

Dalam penelitian ini metode pengumpulan data yang dipakai,adalah:

1. Metode angket (kuesioner)

Dalam penelitian ini, angket digunakan untuk mengetahui dampak persaingan bimbel.

2. Metode dokumentasi

Metode dokumentasi digunakan untuk mengetahui jumlah siswa dan honor guru bimbel di Cibinong Kabupaten Bogor.

\section{Analisis Data}

Untuk mengetahui ada tidaknya pengaruh antara variabel $\mathrm{X}$ dan variabel $\mathrm{Y}$, digunakan tekhnik analisis regresi linear satu variabel, dengan persamaan sebagai berikut:

$\mathrm{Y}=\mathrm{a}+\mathrm{bX}$

Y : Variabel terikat (bimbel konvensional dan bimbel online)

a : konstanta

$\mathrm{b}$ : koefisien regresi variabel $\mathrm{X}$

$\mathrm{X}$ : variabel bebas (gaji guru bimbel)

\section{HASIL DAN PEMBAHASAN}

\section{Hasil Analisis}

Tanpa menafikan berbagai hambatan yang menyertai penyelenggaran bimbingan belajar tidak ada alasan untuk membiarkan begitu saja sistem pembelajaran di bimbingan belajar terus berlangsung dalam keadaan seperti ini. Penyelenggara bimbingan belajar tidak boleh berdiam diri dan menutup mata terhadap kenyataan yang ada bila tidak mau menciptakan ironi dalam pendidikan yaitu keinginan untuk mencerdaskan siswa berubah menjadi membodohi siswa. Tidak ada kata lain kecuali melakukan perbaikan yang dapat dimulai dengan mencoba memandang dengan cara pandang (perspektif) yang baru. Apalagi 
saat ini adalah dimulainya pemberlakuan KBK. Saat ini adalah saat yang tepat untuk merumuskan kembali tujuan dan fungsi bimbingan belajar dan menyesuaikan dengan semangat KBK. Peninjauan Ulang Bimbingan BelajarMelihat kondisi seperti yang disebutkan di atas diperlukan tinjauan ulang tentang sejauh mana peran bimbingan belajar dalam meningkatkan prestasi belajar siswa. Hasil-hasil yang telah dicapai sampai saat ini belum mencerminkan efektivitas dari apa yang telah dijalankan selama ini. Kita tidak menginginkan aktivitas yang telah kita jalankan selama ini menjadi sia-sia. Bukanlah suatu yang bijaksana apabila kita terus mempertahankan kondisi semacam ini. Sudah saatnya untuk mengembalikan posisi kita pada jalur yang sebenarnya

\section{Teknik Analisa data}

\section{Analisis Deskriptif}

Setelah data terkumpul yang diperoleh melalui instrumen yang dipilih, langkah berikutnya adalah mengolah dan menganalisis data untuk menjawab pertanyaan penelitian, atau menguji hipotesis dengan menggunakan SPSS 16. Statistik deskriptif menggambarkan tentang ringkasan data-data penelitian seperti mean, standar deviasi, varian, modus dan lain-lain. Dalam program SPSS digunakan juga ukuran skewness dan kurtosis untuk menggambarkan distribusi data apakah normal atau tidak selain ada beberapa pengujian untuk mengetahui normalitas data dengan uji kolmogorov-Smirnov dan ShapiroWilk.Dalampembahasan ini hanya akan dilakukan analisis deskriptif dengan memberikan gambaran data, tentang jumlah data, minimum, maksimum, mean dan standar deviasi.

\section{Analisis Persyaratan Data}

\begin{tabular}{lcrr} 
Diperlukan & \multicolumn{2}{c}{ sebagai persyaratan } \\
melakukan uji & hipotesis & dengan \\
analisis regresi & pada & statistik \\
parametrik.Uji & persyaratan & datanya \\
adalah uji & normalitas, & uji \\
multikolierritas & dan & uji \\
heteroskedastisitas & (Kusuma & dan \\
Rizki,2017). & &
\end{tabular}

\section{a. Uji normalitas}

digunakan untuk menngetahui apakah populasi data distribusi normal atau tidak. Uji ini biasanya digunakan untuk mengukur data berskala ordinal, interval ataupun rasio. Jika analisis menggunakan metode parametrik, maka persyaratan normalitas harus terpenuhi yaitu data berasal dari distribusi yang normal. Jika data tidak berdistribusi normal atau jumlah sampel sedikit dan jenis data adalah normal atau ordinal maka metode yang digunakan adalah statistik non parametrik. Dalam pembahasan ini akan digunakan uji One Sample Kolmogorov-Smirnov dengan menggunakan taraf signifikansi 0,05 data dinyatakan berdistribusi normal jika signifikansi lebih besar dari $5 \%$ atau 0,05 .

1. Menentukan taraf signifikansi $(\alpha)$ pada penelitian ini menggunakan $\alpha$ $=5 \%$ atau 0,05

2. Penggujian normalitas

Sebelum dilakukan pengujian hipotesis, berdasarkan data-data yang terkumpul dari hasil penelitian ini, terhadap data-data tersebut terlebih dahulu dilakukan uji normalitas. Uji normalitas ini dilakukan dengan menggunakan SPSS 16 yaitu dengan Kolmogorov Smirnov dengan taraf signifikan $\alpha$ $=0,05$ dengan jumlah responden sebanyak 75 orang dengan hipotesis pengujian normalitas sebagai berikut :

$\mathrm{H}_{\mathrm{o}}$ : Data berdistrubsi normal

$\mathrm{H}_{1}$ : Data berdistribusi tidak normal

Kriteria pengujian dengan menggunakan nilai probabilitas (Sig)

Terima $\mathrm{H}_{\mathrm{o}} \quad$ : Jika nilai probabilitas > 0,05 yang berarti data berdistribusi normal 
Tolak $\mathrm{H}_{\mathrm{o}} \quad$ : Jika nilai probabilitas $<0,05$ yang berarti data tidak berdistribusi normal

Hipotesis yang diajukan adalah :

Ho: $\sigma_{1}^{2}=\sigma_{2}^{2}=\ldots=\sigma_{\mathrm{n}}^{2}$ (semua populasi mempunyai varians sama homogen)

$\mathrm{H}_{1}: \sigma_{1}^{2} \neq \sigma_{2}^{2} \neq \ldots \neq \sigma_{\mathrm{n}}^{2}$ (ada popolasi yang mempunyai variasi berbeda/tidak homogen).

b. Uji multikolinearitas

digunakan untuk mengetahui ada atau tidaknya penyimpangan asumsi klasik multikolinearitas yaitu adanya hubungan linear antara variabel independen dalam model regresi. Persyaratan yang harus terpenuhi dalam model regresi adalah tidak adanya multikolinearitas. Pada pembahasan ini akan dilakukan uji multikolinearitas dengan melihat nilai inflation factor (VIF) pada model regresi dan membandingkan nilai koefisien dengan masa individual $\left(r^{2}\right)$ dengan nilai determinasi secara serentak multikolinearitas dengan variabel bebas lainnya.

c. Uji heteroskedastisitas

bertujuan untuk menguji apakah dalam model regresi terjadi ketidaksamaan variance dari residual satu pengamatan ke pengamatan lain. Jika variance dan residual satu pengamatan ke pengamatan lainnya tetap maka disebut homoskedastisitas dan jika berbeda disebut heteroskedastisitas. Kriteria pengujian adalah terjadi heteroskedastisitas apabila gambar scatterplot menunjukan pola tertentu.

\section{d. Uji linearitas}

bertujuan untuk mengetahui apakah dua variabel mempunyai hubungan yang linear atau tidak secara signifikan. Uji ini biasanya digunakan sebagai prasyarat dalam analisis korelasi atau regresi linear. Pengujian pada SPSS dengan menggunakan Test For Linearity dengan pada taraf singnifikansi 0,05 dua variabel dikatakan mempunyai hubungan yang linear bila sisnifikansi (Linearity) kurang dari 0,05 .

\section{e. Uji Homogenitas}

Setelah dilakukan uji normalitas memberikan indikasi bahwa data berdistribusi normal, maka selanjutnya dilakukan uji homogenitas dari sampel penelitian (kelas eksperimen dan kelas kontrol). Uji homogenitas dimaksudkan untuk menguji apakah data berasal dari populasi yang homogen atau tidak. Uji homogenitas data dihitung menggunakan program SPSS versi 16, uji homogenitas tes dilakukan untuk menguji asumsi variance sama atau asumsi variance tidak sama dengan membandingkan P-value dan $\alpha=$ 0,05. Dengan syarat : Jika P-value $\geq \alpha$, maka homogen dan Jika P-value $<\alpha$, maka tidak homogen.

\section{Deskripsi Data}

Deskrisi data hasil penelitian dimaksudkan untuk memberikan gambaran umum mengenai penyebaran / distribusi data, baik berupa ukuran gejala sentral, ukuran letak maupun distribusi frekuensi. Data yang sisajikan adalah data mentah dengan metode statistic deskriptif menggunakan program SPSS versi 16,0 yaitu simpangan baku, modus, median, mean, distribusi frekuensi, kuortosis, skewness serta grafik histogram. Data diperoleh menggunakan tiga instrument dari 75 responden, telah dinyatakan valid dan variabel pada uji coba prapenelitian (Lasmana, 2018).

Sedangkan uraian singkat hasil perhitungan statistik deskriptif disajikan dalam tabel gabungan berikut : 
Tabel 1 Deskripsi Data Penelitian

Statistics

\begin{tabular}{|c|c|c|c|c|}
\hline & & $\begin{array}{c}\text { Bimbel } \\
\text { Konfensional } \\
(\mathrm{X} 1)\end{array}$ & $\begin{array}{l}\text { Bimbel Online } \\
\text { (X2) }\end{array}$ & $\begin{array}{l}\text { Gaji Guru } \\
\text { (Y) }\end{array}$ \\
\hline \multirow[t]{2}{*}{$\mathrm{N}$} & Valid & 75 & 75 & 75 \\
\hline & Missing & 0 & 0 & 0 \\
\hline \multicolumn{2}{|c|}{ Mean } & 97.20 & 89.27 & 14.65 \\
\hline \multicolumn{2}{|c|}{ Median } & 98.00 & 89.00 & 15.00 \\
\hline \multicolumn{2}{|c|}{ Std. Deviation } & 7.476 & 6.481 & 5.419 \\
\hline \multicolumn{2}{|c|}{ Skewness } & -.598 & -.179 & .192 \\
\hline \multicolumn{2}{|c|}{ Std. Error of Skewness } & .277 & .277 & .277 \\
\hline \multicolumn{2}{|c|}{ Kurtosis } & .220 & -.224 & -.939 \\
\hline \multicolumn{2}{|c|}{ Std. Error of Kurtosis } & .548 & .548 & .548 \\
\hline \multicolumn{2}{|c|}{ Range } & 34 & 30 & 21 \\
\hline \multicolumn{2}{|c|}{ Minimum } & 77 & 73 & 4 \\
\hline \multicolumn{2}{|c|}{ Maksimum } & 111 & 103 & 25 \\
\hline
\end{tabular}

Sumber : Penulis 2020

Tabel 2 Uji Normalitas Data Penelitian

One-Sample Kolmogorov-Smirmov test

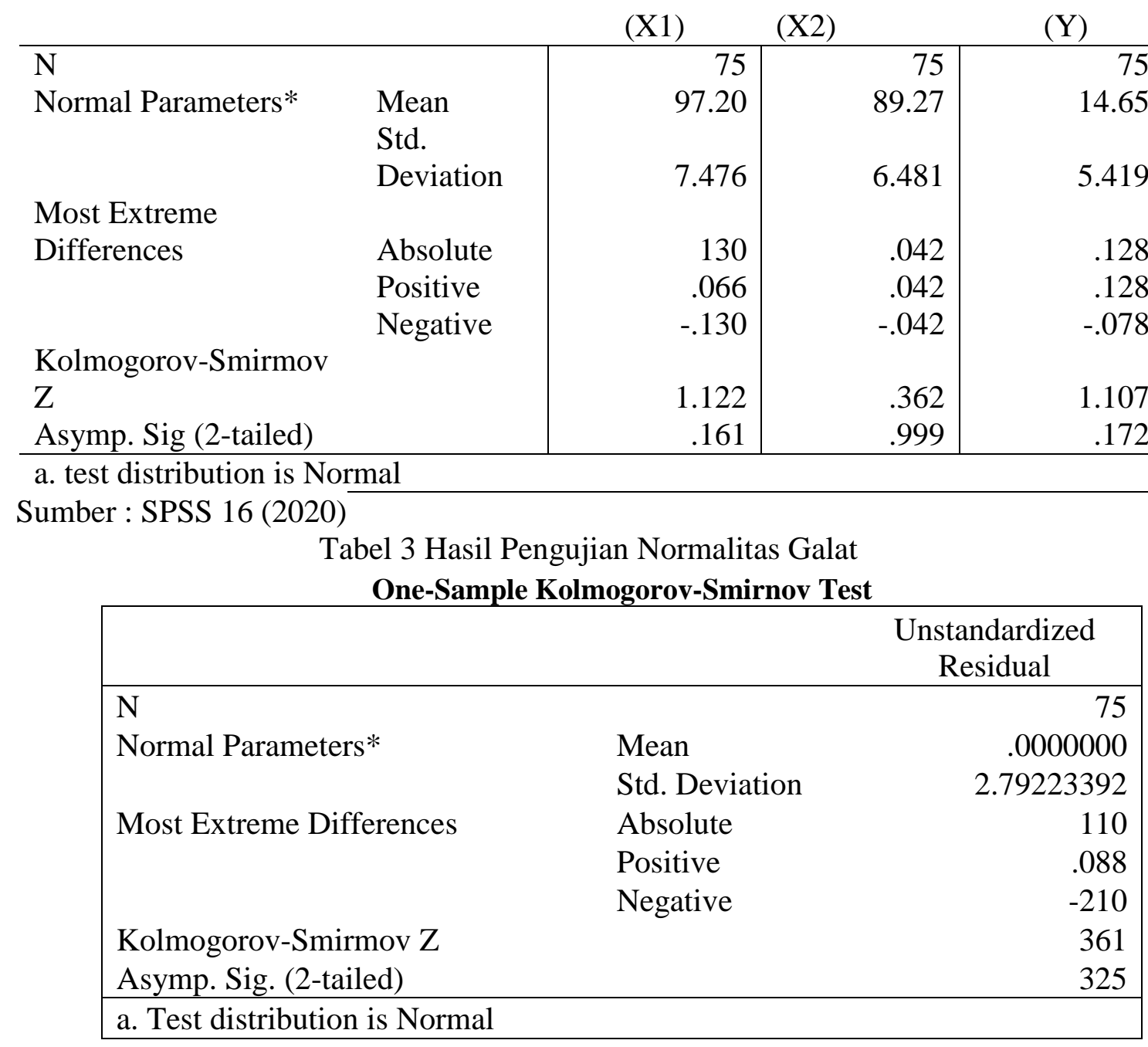


Sumber : SPSS 16 (2020)

Kriteria : Data dikatakan normal apabila sig. $>0.05^{4}$ dari tabel diatas diketahui sig. 0.326 $>0.05^{4}$ jadi dapat disimpulkan data tersebut normal.

\section{Uji Linearitas}

Pengujian Linearitas dalam penelitian ini menggunakan hipotesis sebagai berikut :
Ho : Garis regresi berhubungan antara variabel $\mathrm{X}$ dan variabel $\mathrm{Y}$ linear

$H_{1}$ : Garis regresi berhubungan antara variabel $\mathrm{X}$ dan variabel $\mathrm{Y}$ tidak linear.

Perhitungan dengan menggunakan program SPPS versi 16,0 kriteria dari normalitas data adalah jika sig. > 0.05 maka Ho diterima dan sebaliknya $H_{1}$ ditolak. Ini berarti bahwa garis regresi bersifat linear.

Tabel 4 Uji Linearitas

Model Summary
\begin{tabular}{|rrrrr|}
\hline \multicolumn{7}{|c|}{} & & Adjusted R & Std. Error of the \\
\hline Model & R & R Square & \multicolumn{1}{c|}{ Square } & \multicolumn{1}{c|}{ Estimate } \\
\hline 1 & $.857^{\mathrm{a}}$ & .734 & .727 & 2.831 \\
\hline
\end{tabular}

Sumber : SPSS 16 (2020)

Tabel 5 Uji Simultan

ANOVA $^{b}$

\begin{tabular}{llcrccc}
\hline & & Sum of & & Mean & & \\
Model & & Squares & Df & Squares & F & Sig. \\
\hline 1 & Regression & 1596.040 & 2 & 798.020 & 99.589 & $.000^{\text {a }}$ \\
& Residual & 576.946 & 72 & 8.013 & & \\
& & & & & & \\
& Total & 2172.987 & 74 & & & \\
\cline { 2 - 6 } & & & & & &
\end{tabular}

Sumber : SPSS 16 (2020)

Tabel 6 Uji Parsial

Coefficients $^{\mathrm{a}}$

\begin{tabular}{|c|c|c|c|c|c|}
\hline \multirow[b]{2}{*}{ Model } & \multicolumn{3}{|c|}{$\begin{array}{l}\text { Unstandardized } \\
\text { Coefficients }\end{array}$} & \multirow[b]{2}{*}{$\mathrm{T}$} & \multirow{3}{*}{$\frac{\text { Sig. }}{.000}$} \\
\hline & B & Std. Error & Beta & & \\
\hline 1 (Constant) & -46.918 & 5.216 & & -8.995 & \\
\hline$\left(\mathrm{X}_{1}\right)$ & .612 & .049 & .845 & 12.524 & .000 \\
\hline$\left(X_{2}\right)$ & .023 & .056 & .028 & .410 & .683 \\
\hline
\end{tabular}

Sumber : SPSS 16 (2020) 
Berdasarkan data diatas dapat disimpulkan :

\section{Pengaruh bimbel online dan bimbel} konfensional pada gari guru

Pengujian Hipotesis 1 :

Ho : $\beta_{1}=\beta_{2}=0$

$\mathrm{H}_{1}: \beta_{1} \neq \beta_{2} \neq 0$

Artinya :

$H_{0}$ : Tidak terdapat pengaruh yang signifikan

$H_{1}$ : Terdapat pengaruh yang signifikan

Berdasarkan tabel 4.5 terlihat bahwa koefisien korelasi ganda pengaruh variabel bebas motivasi belajar $\left(X_{1}\right)$ dan $\left(X_{2}\right)$ secara bersama-sama terhadap $(\mathrm{Y})$ adalah sebesar 0,857 . Sedangkan koefisien determinasi ( $\mathrm{R}$ Square) sebesar 73,4\% (mayoritas), sisanya $26,6 \%$ disebabkan oleh faktor lain.

Untuk pengujian hipotesis melalui analisis regresi diperoleh hasil perhitungan seperti dalam tabel 4.6 dan 4.7 berdasarkan tabel 4.7 diperoleh persamaan garis regresi yang mempresentasikan pengaruh variabel $\left(X_{1}\right)$ dan $\left(X_{2}\right)$ terhadap $(Y)$ yaitu $\mathrm{Y}=-46,918+0,612 X_{1}+$ $0,023 X_{2}$ sementara untuk menguju signifikasi garis regresi tersebut adalah dengan memperhatikan hasil perhitungan yang ada pada tabel 4.6 menurut ketentuan yang ada, kriteria signifikasi regresi tersebut adalah jika nilai sig < 0,05 maka Ho ditolak dan $H_{1}$ diterima atau jika $F_{\text {hitung }}>F_{\text {tabel }}$ maka Ho ditolak dan $H_{1}$ diterima yang berarti koefisien regresi signifikan.

Dari tabel 4.6 diketahui bahwa nilai sig $=0.000$ dan $F_{\text {hitung }}=$ 99,589 sedangkan $F_{\text {tabel }}$ dengan sig 0,05 derajat kebebasan $(\mathrm{k})=2$ dan derajat penyebut $(n-k-1)=72$ dengan $\mathrm{n}=$ banyaknya responden $=75, \mathrm{k}=$ banyaknya variabel bebas diperoleh nilai 3,124. Dengan demikian Ho ditolak dan $H_{1}$ diterima sehingga dapat disimpulkan bahwa terdapat pengaruh yang signifikan motivasi belajar bersama-sama terhadap prestasi belajar.

2. Pengaruh bimbel online terhadap gaji guru

Pengujian Hipotesis 2 :

Ho $: \beta_{1}=0$

$\mathrm{H}_{1}: \beta_{1} \neq 0$

Artinya :

$H_{0} \quad$ : Tidak terdapat pengaruh yang signifikan motifasi belajar terhadap prestasi belajar

$H_{1}$ : Terdapat pengaruh yang signifikan motivasi belajar terhadap prestasi belajar

Berdasarkan tabel 4.7 terlihat bahwa sig $=0,000 \quad \operatorname{dan} T_{\text {hitung }}=12,524$ sedangkan $T_{\text {tabel }}$ untuk sig 0,05 dengan derajat kepercayaan $(\mathrm{df}=\mathrm{n}$ 2) $=73$ dengan $n=$ banyaknya responden $=75$ adalah sebesar 1,993. Kriteria signifikasi regresi adalah jika $T_{\text {hitung }}>T_{\text {tabel }}$ maka Ho ditolak dan $H_{1}$ diterima atau jika sig $<0,05$ maka Ho ditolak dan sebaliknya $H_{1}$ diterima. Dengan memperhatikan kriteria tersebut maka Ho ditolak dan $H_{1}$ diterima sehingga dapat

disimpulkan bahwa terdapat pengaruh yang signifikan motivasi belajar terhadap prestasi belajar matematika.

3. Pengaruh bimbel konfensional terhadap gaji guru

Pengujian Hipotesis 3 :

Ho $: \beta_{2}=0$

$\mathrm{H}_{1}: \beta_{2} \neq 0$

Artinya :

$H_{0}$ : Tidak terdapat pengaruh yang signifikan

$H_{1}$ : Terdapat pengaruh yang signifikan 
Berdasarkan tabel 4.7 terlihat bahwa sig $=0,683$ dan $T_{\text {hitung }}=0,410$ sedangkan $T_{\text {tabel }}$ untuk sig 0,05 dengan derajat kepercayaan $(\mathrm{df}=\mathrm{n}-$ 2) $=73$ dengan $n$ banyaknya responden $=75$ adalah sebesar 1,993. Kriteria signifikasi regresi adalah jika $T_{\text {hitung }}>T_{\text {tabel }}$ yaitu $0,410<1,993$ maka Ho ditolak dan $H_{1}$ diterima atau jika sig $<0,05$ sedangkan sig $0,683>0,05$ maka Ho ditolak dan sebaliknya $H_{1}$ diterima. Dengan memperhatikan kriteria tersebut maka Ho diterima dan $H_{1}$ ditolak sehingga dapat disimpulkan tidak terdapat pengaruh yang signifikan

Koefisien korelasi ganda pengaruh variabel bebas motivasi belajar $\left(X_{1}\right)$ dan kepedulian orang tua $\left(X_{2}\right)$ secara bersama-sama terhadap prestasi belajar matematika (Y) adalah sebesar 0,857 sedangkan koefisien determinasi ( $\mathrm{R}$ square) sebesar $73,4 \%$ (mayoritas) sisanya $26,6 \%$ disebabkan oleh faktor lain. Perseamaan garis regresi yang mempresentasikan pengaruh variabel $X_{1}$ dan $X_{2}$ terhadap $\mathrm{Y}$ yaitu $\mathrm{Y}=-46,918+$ $0,612 X_{1}+0,023 X_{2}$ walaupun konstanta dari persamaan bernilai negatif tetapi untuk nilai minimal berturut-turut $X_{1}$ dan $X_{2}$ yaitu 77 dan 73 maka nilai $\mathrm{Y}$ tetap positif yaitu 1,885 koefisien $X_{1}$ dan $X_{2}$ menunjukan adanya pengaruh alternatif secara bersama-sama terhadap Y. Artinya bahwa setiap ada kenaikan nilai satu motivasi belajar maka akan terdapat kenaikan prestasi belajar matematika sebesar 0,612 dan nilai satu kepedulian orang tua maka akan terdapat kenaikan prestasi belajar matematika sebesar 0,023 .

\section{Pengaruh bimbel online terhadap gaji guru \\ Dari pengujian hipotesis diperoleh $T_{\text {hitung }}=12,524$ sedangkan $T_{\text {tabel }}$ untuk sig 0,05 dengan derajat}

kepercayaan $(\mathrm{df}=\mathrm{n}-2)=73$ dengan $\mathrm{n}=$ banyaknya responden $=75$ adalah sebesar 1,993. Kriteria signifikasi regresi adalah jika $T_{\text {hitung }}>T_{\text {tabel }}$ maka Ho ditolak dan $H_{1}$ diterima atau jika sig < 0,05 maka Ho ditolak dan sebaliknya $H_{1}$ diterima. Dengan memperhatikan kriteria tersebut maka Ho ditolak dan $H_{1}$ diterima sehingga dapat disimpulkan bahwa terdapat pengaruh yang signifikan motivasi belajar terhadap prestasi belajar matematika.

2. Pengaruh bimbel konfensional terhadap gaji guru

Dari pengujian terlihat bahwa sig $=0,683$ dan $T_{\text {hitung }}=0,410$ sedangkan $T_{\text {tabel }}$ untuk sig 0,05 dengan derajat kepercayaan $(\mathrm{df}=$ $\mathrm{n}-2)=73$ dengan $\mathrm{n}=$ banyaknya responden $=75$ adalah sebesar 1,993. Kriteria signifikasi regresi adalah jika $T_{\text {hitung }}>T_{\text {tabel }}$ yaitu $0,410<1,993$ maka Ho ditolak dan $H_{1}$ diterima atau jika sig < 0,05 sedangkan sig $0,683>0,05$ maka Ho ditolak dan sebaliknya $H_{1} \quad$ diterima. Dengan memperhatikan kriteria tersebut maka Ho diterima dan $H_{1}$ ditolak sehingga dapat disimpulkan bahwa tidak terdapat pengaruh yang signifikan kepedulian orang tua terhadap prestasi belajar matematika. Dari pengujian dengan SPSS 16 diatas didapat sig. Untuk kepedulian orang tua $0,142>0,05$ dan $F_{0}=3,943$ dengan demikian kesimpulannya adalah tidak terdapat pengaruh kepedulian orang tua yang signifikan terhadap prestasi belajar matematika. Fenomena ini menunjukan bahwa prestasi 
belajar siswa tidak terpengaruh oleh kepedulian orang tuanya.

\section{Kesimpulan}

1. Berdasarkan hasil pengujian hipotesis yang telah dilakukan, Pengaruh persaingan bimbingan belajar (konvensional dan daring) di kabupaten Bogor yang berdampak pada sistem penggajian guru, dapat disimpulkan sebagai berikut:

2. Gaji berpengaruh signifikan terhadap motivasi guru. Dengan demikian dapat dimaknai bahwa semakin baik gaji maka motivasi guru cenderung meningkat.

3. Gaji berpengaruh signifikan terhadap keterampilan mengajar guru. Dengan demikian dapat dimaknai bahwa semakin baik gaji maka keterampilan mengajar cenderung akan meningkat. Motivasi berpengaruh signifikan terhadap keterampilan mengajar guru. Dengan demikian dapat dimaknai bahwa semakin baik motivasi maka keterampilan mengajar cenderung akan meningkat.

4. Keterampilan mengajar berpengaruh signifikan terhadap kinerja guru. Dengan demikian dapat dimaknai jika keterampilan mengajar semakin baik maka kinerja cenderung semakin akan meningkat.

5. Gaji berpengaruh signifikan terhadap kinerja guru. Dengan demikian dapat dimaknai bahwa semakin baik gaji maka kinerja guru cenderung akan meningkat.

6. Motivasi berpengaruh signifikan terhadap kinerja guru. Dengan demi-kian dapat dimaknai bahwa semakin baik motivasi maka kinerja cenderung akan meningkat.

7. Gaji berpengaruh signifikan terhadap kinerja melalui keterampilan mengajar. Hal ini dimaknai bahwa keterampilan mampu memperkuat hubungan antara gaji terhadap kinerja guru. Artinya keterampilan mengajar berperan dalam meningkatkan hubungan gaji terhadap kinerja.

8. Motivasi berpengaruh signifikan terhadap kinerja melalui keterampilan mengajar guru. Dengan demikian dapat dimaknai jika motivasi semakin baik maka kinerja akan semakin baik pula dengan meningkatnya juga keterampilan mengajar. Artinya motivasitinggi akan mempengaruhi kinerja tinggi dengan keterampilan mengajar yang tinggi juga. Keterampilan memperkuat hubungan motivasi terhadap kinerja.

\section{Saran}

Berdasarkan kesimpulan di atas, maka untuk meningkatkan kinerja, maka dapat disarankan:

1) Kepada Yayasan sekolah lebih memperhatikan kesejahteraan guru dengan pemberian gaji yang sesuai atau keadilan, kompetetif, sesuai prosedur dan memotivasi. Karena apabila guru merasa tercukupi kebutuhannya maka guru akan fokus pada pekerjaannya sehingga guru termotivasi untuk meningkatkan kemampuannya dan menghasilkan kinerja yang baik. Sehingga tujuan pembelajaran khususnya dan tujuan pendidikan umumnya dapat tercapai.

2) Kepada guru-guru untuk meningkatkan kemampuannya dengan banyak mengikuti pelatihanpelatihan, workshop, dan melanjutkan studi untuk menambah wawasan guru 


\section{DAFTAR PUSTAKA}

Lasmana, A. (2018). Persepsi Mahasiswa Mengenai Pengaruh Ipk (Indeks Prestasi Kumulatif), Penghargaan Finansial Dan Lingkungan Kerja Terhadap Pemilihan Profesi Akuntan Publik. JURNAL AKUNIDA, 4(1), 61-75.

Abdulsyani, 1994. Sosiologi Skematika, Teori dan Terapan. Jakarta: Bumi Aksara.

Depdikbud. 2003. Undang-Undang RI No. 20 Tahun 2003 Tentang Sistem Pendidikan Nasional. Semarang: Aneka Ilmu.

Kusuma, I. C., \& Rizki, L. M. (2017). Pengaruh Intelegence Quotient (IQ), Emotional Quotient (EQ), Dan Spiritual Quotient (SQ) Terhadap Pemahaman Akuntansi Siswa Di Smk Sumpah Pemuda 2. JURNAL AKUNIDA, 3(1), 29-39.

Poerdarminta Wjs.1990. Kamus Bahasa Indonesia, PN.Jakarta: Balai Pustaka

Soerjono Soekanto, 2002. Sosiologi Suatu Pengantar. Jakarta:Rajawali Press

Sudjarwo .S， 2004.Buku Pintar Kependudukan. Jakarta: PT Gramedia Widiasarana Indonesia.

Tantan suhartan,2013. Statistik Sosial dan Kependudukan siswa smpn 2 sukahening. Hasil Susenas. Tasikmalaya : PS.

Pandi Anoraga. 2010. Ekonomi Islam

Kajian Makro dan Mikro. Yogyakarta
Triwidatin, Y. (2019). Pengaruh Kondisi Sosial Ekonomi Orang Tua Terhadap Prestasi Mahasiswa Akuntansi Bogor. JURNAL AKUNIDA, 5(2), 85-99.

www.postmedya.com www.kajianpustaka.com 